\author{
Jun/2019 \\ Working Paper 19-13 \\ rcea.org/RePEc/pdf/wp19-13.pdf

\section{NON-PERFORMING LOANS AND SOVEREIGN CREDIT RATINGS}

\author{
Periklis Boumparis \\ University of Liverpool, UK \\ Costas Milas \\ University of Liverpool, UK \\ RCEA \\ Theodore Panagiotidis \\ University of Macedonia, Greece \\ RCEA
}

Copyright belongs to the author. Short sections of the text, not exceeding three paragraphs, can be used provided proper acknowledgement is given.

The Rimini Centre for Economic Analysis (RCEA) was established in March 2007. RCEA is a private, nonprofit organization dedicated to independent research in Applied and Theoretical Economics and related fields. RCEA organizes seminars and workshops, sponsors a general interest journal, the Review of Economic Analysis (REA), and organizes a biennial conference, the Rimini Conference in Economics and Finance (RCEF). Scientific work contributed by the RCEA Scholars is published in the RCEA Working Paper series.

The views expressed in this paper are those of the authors. No responsibility for them should be attributed to the Rimini Centre for Economic Analysis. 


\section{Non-performing loans and sovereign credit ratings}

\author{
Periklis Boumparis \\ University of Liverpool, \\ United Kingdom \\ P.Boumparis@liverpool.ac.uk
}

\author{
Costas Milas* \\ University of Liverpool, \\ United Kingdom \\ and \\ Rimini Centre for Economic \\ Analysis, Rimini, Italy \\ costas.milas@liverpool.ac.uk
}

\author{
Theodore Panagiotidis \\ Department of Economics, \\ University of Macedonia, Greece \\ tpanag@uom.gr
}

This paper examines the joint behaviour of sovereign ratings and their macroeconomic/financial determinants (namely uncertainty, GDP growth, government debt-to-GDP ratio, investment-to-GDP ratio and the fiscal balance-to-GDP ratio) in a multivariate Panel Vector Autoregressive (PVAR) framework. We reveal another channel of interconnection between sovereign and banking credit risk by identifying a two-way relationship between non-performing loans (NPLs) and sovereign ratings. Generalized impulse response functions (GIRFs) provide evidence of significant effects from NPLs on sovereign rating decisions over and above the effects of the remaining economic/financial variables. At the same time, sovereign rating decisions impact on NPLs and all other variables.

JEL classification: G24; E44; C33

Keywords: Sovereign credit ratings; Non-performing loans; Panel VAR

*Address for correspondence: Professor Costas Milas, Management School, University of Liverpool, Chatham Street, L69 7ZH, Liverpool, United Kingdom.

Phone number: +441517953135. Email: costas.milas@liverpool.ac.uk

We thank Michael Sigmund (Oesterreichische Nationalbank) and Robert Ferstl (University of Regensburg) for discussing how to best apply their panelvar package in $\mathrm{R}$ (available from: https://cran.r-project.org/web/packages/panelvar/index.html). We thank Jane Binner (University of Birmingham), Steven Davis (Chicago Booth School of Business), Michael Ellington (University of Liverpool), Chris Florackis (University of Liverpool), Alexandre Jeanneret (HEC Montréal), Alex Kostakis (University of Liverpool), Michael O'Grady (Central Bank of Ireland) Themis Pavlidis (Lancaster University), Lucio Sarno (CASS Business School), George Skiadopoulos (Queen Mary University of London), Michalis Stamatogiannis (University of Liverpool) and Kostas Vasilopoulos (Lancaster University) for useful comments. Any remaining errors are our own. 
“... you could almost say that we live again in a twosuperpower world. There is the U.S. and there is Moody's. The U.S. can destroy a country by leveling it with bombs; Moody's can destroy a country by downgrading its bonds" Thomas L. Friedman 22/2/1995 New York Times https://www.nytimes.com/1995/02/22/opinion/foreignaffairs-don-t-mess-with-moody-s.html

\section{Introduction}

In its January 2019 World Economic Outlook, the International Monetary Fund (IMF) noted that while global growth of 3.7\% in 2018 remained close to post-crisis highs, global expansion will somewhat weaken to $3.5 \%$ in $2019 .{ }^{1}$ In fact, policymakers around the world have little room for complacency about future economic growth; for instance, (former) IMF Economic Counsellor and Director of Research Maurice Obstfeld (2018) noted that "as important as they have been to the recovery, easy financial conditions and fiscal support have also left a legacy of debt - government, and in some cases, corporate and household - in advanced and emerging economies alike." 2

The ongoing debt hangover brings again into focus the issue of assessing the probability of a (sovereign) default. This remains an important and unresolved issue not least because of the difficulty of providing an accurate estimate of such probability that can create information asymmetry between governments, banks, corporations and investors. This information gap has been traditionally filled by Credit Rating Agencies (hereafter CRAs) that publish sovereign credit ratings as measures of the probability that a country will repay its debt in full and on time. Therefore, sovereign ratings influence to a large extent borrowing costs in international markets both for a sovereign state and the financial institutions operating in that sovereign state (see e.g. Drago and Gallo, 2017a) which, in turn, affects the lending supply of banks (Drago and Gallo, 2017b) as well as investment decisions and ultimately economic growth (see e.g. Chen et al., 2016).

\footnotetext{
1 See https://blogs.imf.org/2019/01/21/a-weakening-global-expansion-amid-growing-risks/.

2 According to the IMF World Economic Outlook Database, general government gross debt in advanced economies, at $102.8 \%$ of Gross Domestic Product (GDP) in 2018, will remain some 32 percentage points above its pre-crisis level in 2007. General government gross debt in emerging market and developing economies, at 51\% of GDP in 2018, will remain some 15 percentage points above its pre-crisis level.
} 
With so much at stake in terms of future financial repayments and investment planning, it is not surprising that the way CRAs assess credit scores has received increasing attention. Criticism has focussed on the inability of CRAs to predict corporate defaults that took place in the US during 2007-2008 (see e.g. Baghai et al., 2014), their potential role in the acceleration of the sovereign debt crisis by massively downgrading Eurozone periphery bonds (see e.g. Boumparis et al., 2017) and on the effect of subjectivity in their assessment methods (see De Moor et al., 2018). ${ }^{3}$ Decisions by CRAs have indeed been questioned by policymakers. In 2012, for instance, both European Central Bank (ECB) President Mario Draghi and (at the time) Bank of England Governor Mervyn King urged investors to pay less attention to CRAs and to make up their own minds about how much the region's debt is worth. ${ }^{4}$

This paper takes the issues raised above to the data by modelling the behavior of sovereign ratings in the case of the three main CRAs, namely Moody's Investor Services, Standard \& Poor's (S\&P's) and Fitch Ratings. ${ }^{5}$ We extend recent literature (see e.g. Reusens and Croux, 2017; Boumparis et al. 2017; and references therein) by identifying a feedback loop between sovereign credit ratings and non-performing loans (NPLs) as a measure of banking risk over and above the impact of macroeconomic and financial determinants, namely uncertainty, GDP growth, government debt-to-GDP ratio, investment-to-GDP ratio and the fiscal balance-to-GDP ratio. This is done within a Panel Vector AutoRegressive (PVAR) model which allows us to tackle endogeneity issues that arise since sovereign ratings respond to but also cause country-specific macroeconomic and financial developments.

\footnotetext{
${ }^{3}$ Herding bahavior issues are also at play. For instance, Lugo et al. (2015) assess the herding behavior of CRAs in the US Home Equity Loan market to find that since the start of the subprime crisis, rating convergence is more likely when Fitch rather than the rival (Moody's or S\&P's) has to adjust its evaluation downwards.

${ }^{4}$ In January 2012, Mario Draghi told the European Parliament in Strasbourg that "we should learn to do without ratings, or at least we should learn to assess creditworthiness" adding that "certainly one needs to ask how important are these ratings for the marketplace overall, for investors", whereas Mervyn King stressed (also in January 2012) in a parliamentary committee in London that one should "put less focus directly on what the ratings agencies say and more on what the market as a whole is saying in terms of sovereign debt" adding that "what we need to do is to move to a point, and I think markets have gone some way towards that, where they pay less attention to the verdicts of the ratings agencies". See http://www.nytimes.com/2012/01/18/business/global/european-central-bankers-criticize-role-ofrating-agencies.html.

5 These CRAs collectively control around $95 \%$ of the market. See http://www.bbc.co.uk/news/business$\underline{36629099 .}$.
} 
There are good reasons to suggest a strong connection between sovereign and bank credit risk. In Acharya et al. (2014), for instance, a distressed financial sector induces government bailouts, whose cost increases sovereign credit risk. Increased sovereign credit risk, in turn, weakens the financial sector by eroding the value of its government guarantees and bond holdings. Adelino and Ferreira (2016) show that the rating score of banks with a profile equal to or higher than that of their sovereign state is affected more by sovereign downgrades compared to banks with a lower rating profile than their sovereign state. Mäkinen et al. (2018) link sovereign risk to bailouts in the banking sector and note that rising policy uncertainty weakens the ability of governments to provide bailouts. Gennaioli et al. (2014) focus on the dire consequences of sovereign default on aggregate financial activity in the defaulting country; the impact is stronger in countries where domestic banks hold more public debt. Altavilla et al. (2017) flag the amplification effect of sovereign stress on bank lending to domestic firms for a sample of euro-area banks. All the above point to a strong feedback loop between sovereign and banking risk. It, therefore, comes as no surprise that banking risk has recently appeared on the radar of CRAs. For instance, S\&P's recent update of its assessment methodology (S\&P's Global Ratings, 2017) refers to contingent liabilities and their potential impact on sovereign ratings. Among these liabilities that have the potential to become government debt, or more broadly affect a government's fiscal profile, bank NPLs ${ }^{6}$ have increased rapidly after 2008 not least in the Euro area adding to regulatory concerns. ${ }^{7}$ In 2016 , for instance, the European Banking Authority (EBA) flagged high NPLs as one of the main risks for EU banks, whereas in 2017, the ECB stressed that high NPLs have a negative impact on bank lending to the economy as a result of profitability and capital constraints and also flagged the benefits of a reduction of NPLs to the economy from both a microprudential and a macroprudential perspective. ${ }^{8}$ Thus, it is not surprising that CRAs consider changes in NPLs as an important driver of rating changes. For example, S\&P's latest report on Greece

\footnotetext{
6 These are loans where the full repayment of the principal and interest may no longer be expected. Typically, the principal or interest would be at least 90 days in arrears, although the precise definition of NPLs varies across jurisdictions.

7 For instance, NPLs increased from $4.67 \%$ of total gross loans in 2008 to $36.29 \%$ in 2016 in Greece and from 3.59\% in 2008 to $48.67 \%$ in 2016 in Cyprus. For the Euro area NPLs increased from $2.80 \%$ in 2008 to $4.05 \%$ in 2016.

8 See

https://www.eba.europa.eu/documents/10180/1315397/EBA+Risk+Assessment+Report_December+ 2016.pdf and https://www.bankingsupervision.europa.eu/ecb/pub/pdf/guidance on npl.en.pdf.
} 
notes "Another potential trigger for an upgrade would be a marked reduction in nonperforming assets in Greece's impaired banking system". ${ }^{9}$

In recent work, Brůha and Kočenda (2018) examine the link between banking sector quality and sovereign risk to show that rising NPLs is the single most influential sectorspecific variable that is associated with increased sovereign risk in the European Union. In addition, rising NPLs have often been considered the consequence of weak economic growth but, at the same time, feedback themselves in a negative manner to the banking sector and the wider economy. Indeed, NPLs have been shown to be a significant predictor of bank failures. But even in the case where banks avoid failure, rising NPLs have a negative impact on the cost structure and efficiency of banks as well as their willingness to lend (see e.g. Balgova et al., 2016) and, as a result, undermine future economic growth.

This very discussion indicates that NPLs are an appropriate measure of banking risk and opens up the possibility that developments in NPLs affect sovereign rating decisions over and above the impact of other control variables. On the other hand, sovereign ratings impact negatively on NPLs through banking ratings and lending supply. This two-way feedback is examined within a panel VAR of 72 countries over the 1998-2016 period.

First, we identify a significant negative effect of NPLs on sovereign credit ratings and vice versa. Second, uncertainty shocks trigger a negative effect on sovereign rating decisions following the financial turmoil and the subsequent Eurozone crisis. Indeed, uncertainty is firmly now on the radar of CRAs; Moody's, for instance, notes (in May 2018) uncertainty in Italy as a reason for a credit rating review. ${ }^{10}$ From a theoretical point of view, uncertainty shocks could undermine the expected profitability of firms, which puts upward pressure on their perceived riskiness. In this context, investors demand higher interest rates to be compensated for the higher risk and consequently that issuance of additional debt becomes more costly and adversely affects investments (see e.g. Gilchrist et al., 2014).

Our results provide additional insight towards understanding how CRAs make sovereign credit rating decisions by flagging the importance of NPLs in driving these decisions. With

\footnotetext{
${ }^{9}$ See https://www.standardandpoors.com/en_US/web/guest/article/-/view/type/HTML/id/2075495. 10 Something that triggered the reaction of Five Star leader Di Maio who wrote that "governments are decided by the credit rating agencies". See https://www.bloomberg.com/news/articles/2018-05-27/italys-president-vetoes-candidacy-of-euroskeptic-savona.
} 
this in mind, our results should be useful to regulators like the European Securities and Markets Authority (ESMA) who monitor CRAs in order to understand their rating methodology and assess the quality of their ratings. Our results should also be informative for investors who can rely on our findings to get additional clarity on how CRAs reach their sovereign assessment decisions. This will go some way towards restoring part of the investor confidence towards CRAs which was undermined following the recent financial crisis and the heavy criticism CRAs received (and indeed continue to receive) by policymakers during the Eurozone crisis and beyond.

The structure of the paper is as follows. Section 2 discusses our dataset. Section 3 introduces the panel VAR model and Section 4 presents and discusses the empirical estimates. Finally, Section 5 offers some concluding remarks.

\section{Data description}

We use $T=19$ annual observations over the 1998-2016 period for a panel of $N=72$ countries. ${ }^{11}$ Our main variable of interest is the sovereign credit rating published by the three main international rating agencies, Moody's, S\&P's and Fitch Ratings (attributed at the $31^{\text {st }}$ of December of each calendar year). In our main model, we implement a linear transformation of credit ratings to numerical scale (see also Boumparis et al., 2017 and references therein), starting from 21 for the highest quality with a stable outlook (AAA for Fitch and S\&P's and Aaa for Moody's) and ending to 1 for Default (D for Fitch and S\&P's and C for Moody's). We consider both changes in credit ratings and changes in credit outlooks. For our sovereign rating variable, the difference between two continuous outlooks is always equal to $1 / 3$, so the difference between two continuous ratings with the same outlook is always equal to one. Table 1 reports the linear transformation of

\footnotetext{
11 The countries included are: United Arab Emirates, Argentina, Armenia, Australia, Austria, Belgium, Bulgaria, Bolivia, Brazil, Canada, Switzerland, Chile, China, Colombia, Costa Rica, Cyprus, Czech Republic, Germany, Denmark, Dominican Republic, Ecuador, Spain, Estonia, Finland, France, Gabon, The United Kingdom, Georgia, Ghana, Greece, Hong Kong, Croatia, Hungary, Indonesia, India, Ireland, Iceland, Israel, Italy, Japan, Korea Republic, Lithuania, Luxembourg, Latvia, Morocco, Moldova, Mexico, F.Y.R.O.M., Malta, Malaysia, The Netherlands, Norway, New Zealand, Pakistan, Philippines, Poland, Portugal, Paraguay, Romania, Russian Federation, Saudi Arabia, Singapore, Slovak Republic, Slovenia, Sweden, Thailand, Tunisia, Turkey, Ukraine, Uruguay, The United States and South Africa. Due to missing observations, our dataset includes 1226 observations for Moody's, 1253 observations for S\&P's and 1190 observations for Fitch.
} 
credit ratings and provides details on the frequencies of the ratings per category. We also consider the logistic transformation of ratings in the robustness section of the paper.

Our PVAR framework (details of the theoretical model are given in the next section of the paper) allows us to examine jointly sovereign ratings and a number of factors. In particular, we implement a PVAR model which includes Uncertainty, GDP growth rate, total investments (as \% of GDP), gross government-debt (as \% of GDP), fiscal balance (as $\%$ of GDP), NPLs (non-performing loans as \% of total gross loans) and sovereign credit ratings as endogenous variables.

We incorporate stock price volatility as a country specific proxy of uncertainty ${ }^{12}$. Increased uncertainty is expected to trigger sovereign rating downgrades as it makes consumers and investors more cautious and reduces consumption and investment (Boumparis et al., 2017). For example, S\&P's lists uncertainty as one of the main reasons driving its unprecedented decision to downgrade the US in $2011 .{ }^{13}$ On the other hand, a rating downgrade creates weaker economic conditions which, in turn, increase uncertainty. This is because governments are more likely to change their policy to deal with weak economic conditions and it, therefore, becomes increasingly uncertain which of the potential policies will be adopted (Pástor and Veronesi, 2013).

GDP growth impacts positively on sovereign ratings and vice versa (see e.g. Chen et al., 2016 and Reusens and Croux, 2017, and references therein). An increase in investments triggers sovereign rating upgrades as they enhance the country's economic prospects. On the other hand, a rating downgrade reduces investments by affecting the cost of capital and changing the net present value of some projects from positive to negative (see Chen et al., 2016 and Chen et al., 2013). An increase in government debt triggers sovereign rating downgrades because a high stock of government debt implies higher interest rates to service it. Hence, additional financial resources are needed to repay debt obligations and therefore, a higher government debt should increase the risk of default. On the other hand, the impact of sovereign ratings on government debt is uncertain. This is because rating upgrades decrease sovereign spreads and make debt repayment cheaper which

\footnotetext{
${ }^{12}$ Volatility of stock price index is the 360-day standard deviation of the return on the national stock market index. (Bloomberg). This is available from the Federal Reserve Bank of St Louis database. 13 See https://www.reuters.com/article/us-usa-sp-downgrade-text/sp-lowers-united-states-creditrating-to-aa-idUSTRE7750D320110806.
} 
might reduce the pile of debt. At the same time, however, political business cycle considerations suggest that governments might exploit the opportunity of the positive sentiment in financial markets following a rating upgrade and adopt expansionary fiscal policies to increase the probability of an electoral victory. ${ }^{14} \mathrm{~A}$ fiscal surplus or very low fiscal deficit indicates strong fiscal performance which, in turn, triggers sovereign rating upgrades. On the other hand, the impact of the sovereign rating on the fiscal balance is uncertain. This is because rating upgrades decrease sovereign spreads and reduce the amount needed to be paid on interest rates each year. At the same time, however, political business cycle considerations might trigger expansionary fiscal policies leading to a deterioration of the fiscal balance.

We expand the information set by including NPLs in the specification. Rising NPLs lead to sovereign rating downgrades as they increase the possibility of a bailout to the banking sector that sets an additional fiscal burden and undermines the country's economic prospects. On the other hand, sovereign downgrades lead to a rise in NPLs. This is because sovereign rating downgrades lead to banking rating downgrades which in turn lead to a reduction in lending supply and, at the same time, increase the burden of refinancing existing loans, therefore, making it more likely than not that NPLs will increase. Table 2 provides details of the data definitions and sources and Table 3 reports the data summary statistics.

\section{Methodology}

We follow the estimation approach of Binder et al. (2005) and the implementation and extension by Sigmund and Ferstl (2019) and consider a PVAR model with fixed effects:

$y_{i, t}=\mu_{i}+\sum_{l=1}^{p} A_{l} y_{i, t-1}+\varepsilon_{i, t}$

\footnotetext{
${ }^{14}$ Duygun et al. (2016) find that a rating upgrade is likely to increase sovereign debt because of sovereign ratings' procyclicality and path dependence. Nevertheless, they also find that the impact of sovereign rating decisions on debt varies with the degree of the country's institutional quality; in particular, rating upgrades in countries with higher institutional quality are followed by debt reductions and an improvement in the fiscal balance.
} 
where $y_{i, t} \in \mathbb{R}^{m}$ is an $(m \times 1)$ vector of endogenous variables for the $i$-th cross-sectional unit $(i=1,2, \ldots, N)$ at time $t(t=1,2, \ldots, T), \boldsymbol{\varepsilon}_{i, t} \in \mathbb{R}^{m}$ is an $(m \times 1)$ vector of disturbances, $\mu_{i}$ is an ( $m \times 1)$ vector of individual-specific effects, and $p$ is the lag length of the PVAR model. Stationarity requires all unit roots of the model lie inside the unit circle. Parameter homogeneity for the $(m \times m) A_{l}$ matrix is assumed. A PVAR model is hence a combination of a single equation dynamic panel model (DPM) and a vector autoregressive model (VAR).

Applying the first difference transformation to (1) we get:

$\Delta y_{i, t}=\sum_{l=1}^{p} A_{l} \Delta y_{i, t-l}+\Delta \varepsilon_{i, t}$,

where $\Delta$ refers to the first difference operator. ${ }^{15}$

Following Binder et al. (2005), the moment conditions for the lagged endogenous and the predetermined variables are:

$E\left[\Delta \varepsilon_{i, t} y_{i, j}^{T}\right]=0$

with $j \in\{1, \ldots, T-2\}$ and $t \in \mathbb{T}_{\Delta}$. By stacking over $t$, (2) is written as:

$\Delta Y_{i}=\sum_{l=1}^{p} \Delta Y_{i, l} A_{l}^{T}+\Delta E_{i}$

where $\Delta Y_{i}, \Delta Y_{i, l}$ and $\Delta E_{i}$ are $((T-1-p) \times m)$ matrices. Thus, the stacked moment conditions for each $i$ is as follows:

15 The first difference transformation exists for $t \in\{p+2, \ldots, T\}$. We denote the set of indexes $t$, for which the transformation exists by $\mathbb{T}_{\Delta}$. Using the forward orthogonal transformation of Arellano and Bover (1995) produced qualitatively similar results to what we report below (these results are available on request). 
where $\mathrm{Q}_{i}$ is the stacked form of $q_{i, t}$ with $q_{i, t}^{\mathrm{T}}:=\left(y_{i, t-p-1}^{\mathrm{T}}, y_{i, t-p-2}^{\mathrm{T}}, \ldots, y_{i, 1}^{\mathrm{T}}\right)$, for $t \in\{p+2, \ldots, T\}$ and

$Q_{i}:=\left(\begin{array}{cccc}q_{i, p+2}^{T} & 0 & \cdots & 0 \\ 0 & q_{i, p+3}^{T} & & 0 \\ \vdots & & \ddots & \vdots \\ 0 & 0 & \cdots & q_{i, T}^{T}\end{array}\right)$

Based on the moment conditions (5), the minimization problem is:

$\min _{\Phi}\left\{\sum_{i=1}^{N} Z_{i}^{T}\left(\Delta Y_{i}-\left[\Delta Y_{i,-1}\right] \Phi\right)^{T} \Lambda_{z}^{-1} \sum_{i=1}^{N} Z_{i}^{T}\left(\Delta Y_{i}-\left[\Delta Y_{i,-1}\right] \Phi\right)\right\}$

where $\Phi$ delivers the Generalized Method of Moments (GMM) estimates of model (2) and $\Lambda_{z}$ is the weighting matrix based on the one-step estimation procedure of Binder et al. (2005); see also the detailed technical discussion in Sigmund and Ferstl (2019).

The choice of the optimal weighting matrix reduces the asymptotic bias in the estimation. Fixed effects are removed by implementing first differences.

There are $m=7$ endogenous variables in our PVAR model such that the vector $\mathrm{y}_{i, t}$ is given by $\mathrm{y}_{i, t}=$ [Uncertainty, GDP growth, Investments, Debt, Fiscal Balance, NPLs, rating] using a lag length of $p=2$ and employing 3 lags of all endogenous variables as instruments. ${ }^{16}$ The choice of the lag length is based on the Andrews and Lu (2001) model and moment selection criteria (MMSC). ${ }^{17} \mathrm{~A}$ choice of 2 lags appears justified also on

16 The literature on sovereign ratings (see e.g. Afonso et al., 2011) often models ratings as a function of GDP growth and the unemployment rate. To keep the dimensionality of the PVAR model as manageable as possible, we use GDP growth in our model. In any case, the impact of the unemployment rate on sovereign ratings is indirectly captured by the impact of GDP growth through an Okun's-law type of approximation (in which case there is an inverse relationship between unemployment and GDP growth).

17 For instance, using Moody's model and implementing the first difference transformation, the MMSC-HQIC (Hannan-Quinn Information Criterion) is equal to 54875.93 using 2 lags and equal to 71125.55 using 1 lag. 
economic grounds as there is evidence of persistence and stickiness in rating decisions (Dimitrakopoulos and Kolossiatis, 2016); considerable persistence also shows up in some of the impulse responses reported in the following section of the paper.

To examine the response of one (endogenous) variable to an impulse in another (endogenous) variable, we rely on Generalized Impulse Response Functions (GIRFs) of Pesaran and Shin (1998); contrary to Orthogonalized Impulse Response Functions (OIRFs; where the underlying shocks to the model are orthogonalized using the Cholesky decomposition before calculating impulse responses), GIRFs are not affected by the ordering of the variables in the PVAR model and fully take account of the historical patterns of correlations observed amongst the different shocks. The justification of GIRFs over OIRFs is twofold. First, the theoretical framework for this strand of the empirical literature is limited at best ${ }^{18}$ and, second, the large number of variables we employ makes an appropriate ordering almost impossible. ${ }^{19}$ In what follows, we report GIRFs with 95\% confidence intervals estimated using bootstrap cross-sectional resampling (Kapetanios, 2008). ${ }^{20}$

\section{Empirical results}

\subsection{Main estimates}

We calculate and report GIRFs to one standard error shocks for all CRAs based on the first difference transformation (stability condition is satisfied in all cases). Figures 1 to 3 report GIRFs for the three CRAs using the first difference transformation.

An uncertainty shock impacts negatively on the sovereign ratings assigned by all CRAs; the impact is statistically significant for all CRAs dies out after 2 years for S\&P's and Fitch but it is long lasting for Moody's. A positive GDP growth rate shock impacts positively on CRA decisions; the effects last for almost 6 years for Moody's and for 5 years for S\&P'S and Fitch. A positive investment shock leads to sovereign rating upgrades. The duration

All MMSC-HQIC, MMSC-BIC (Bayesian Information Criterion) and MMSC-AIC (Akaike Information Criterion) selection criteria suggest 2 lags for all PVAR models employed in our paper.

${ }^{18}$ See Holden at al. (2018) for an equilibrium theory that allows for the possibility that ratings affect the performance of the rated objects.

${ }^{19}$ Granger causality tests within our PVAR model (available on request) do not provide clear guidance on the ordering of the variables as they indicate bidirectional causality.

${ }^{20}$ We use 500 bootstrap replications in all calculations. 
of the effect varies from 5 years for Moody's to 3 years for S\&P's and to 2 years for Fitch. The latter results suggest that Moody's assigns a higher weight on investments than the remaining rating agencies.

A positive shock to government debt has a negative and persistent effect on sovereign ratings. A positive shock to fiscal balance has a positive and persistent effect on sovereign ratings. The impact of a government debt shock is statistically important for up to 6 years for Moody's, 8 years for S\&P's and 10 years for Fitch, while a shock on fiscal balance impacts on sovereign ratings for more than 10 years. Therefore, fiscal considerations in terms of fiscal balance trigger a longer impact on the rating decisions made by the three CRAs compared to government debt developments.

The persistence of the effect is arguably not surprising given the stickiness of sovereign ratings and the importance of fiscal variables for default risk. All in all, CRAs have been very careful and patient in changing credit ratings considering their effect in financial markets and the real economy. So, rating upgrades/downgrades are very rare apart from periods of financial turmoil. Rating's persistence has been also well documented in the literature. Dimitrakopoulos and Kollosiatis (2014) examine three potential sources of ratings persistence. True state dependence, spurious state dependence and serial error correlation. They provide evidence of the three channels of the observed ratings persistence, with the true state dependence being weak. Consequently, our GIRFs are in line with observed credit ratings and previous literature.

Turning our attention to NPLs, our model confirms their importance for sovereign rating decisions. A positive shock to NPLs leads to sovereign rating downgrades with the impact being statistically stronger and economically more prolonged for Moody's (up to 6 years). From Figures 1-3, we also note that positive shocks to sovereign ratings do have an impact on uncertainty and trigger a positive effect on GDP growth for all CRAs. The impact on Uncertainty and GDP growth, which is similar for all CRAs, reaches its peak after 2 years and remains statistically significant for up to 4 years. Investments also respond positively to positive sovereign rating shocks. The impact is maximized after 3 years for all agencies and lasts (from a statistical point of view) for almost 8 years. Positive shocks to sovereign ratings do have a positive impact on fiscal balance and government debt. The impact on government debt is maximized after 3 years and is persistent and statistically significant for up to 8 years for Moody's and slightly less so (up to 7 years) for S\&P's and 
Fitch, while, for all CRAs, a positive sovereign rating shock exerts a statistically significant and positive impact on the fiscal balance for up to 4 years.

Last but not least, positive shocks to sovereign ratings reduce NPLs. The impact reaches its peak after 3 years and is long lasting (up to 9 years for Moody's and up to 10 years for S\&P's and Fitch) and the magnitude of the impact of the shock at peak (after 3 years) is stronger for Moody's (that is, a negative change of approximately 2 percentage points following a one standard error positive shock in the equation for sovereign ratings).

To sum up, GIRFs provide evidence of significant effects from NPLs on sovereign rating decisions over and above the effects of the remaining economic/financial variables; at the same time, sovereign ratings impact on NPLs and all other variables.

\subsection{Robustness checks}

\subsubsection{A logistic transformation of sovereign ratings}

So far our results have been based on the linear transformation of sovereign ratings from letters to numbers. This implies that the distance between two subsequent ratings is always the same. Among others, Afonso et al. (2011) and Boumparis et al. (2017) have considered a logistic transformation of sovereign ratings instead of a linear one. The logistic transformation is given by $L_{l}=\ln \left[R_{l} /\left(1-R_{l}\right)\right]$, where $R_{l}=(2 l-1) /\left(2 n_{c}\right)$, the number of categories, $n_{c}$, equals 21 and (from the last column of Table 1 ) the rating grades are $l=1,2, \ldots, 21$. Figure 4 plots together the linear and logistic transformation for Moody's sovereign credit ratings.

In the logistic transformation, the differences between categories are not constant but are still imposed a priori. Consequently, we performed again our analysis using the logistic transformation of sovereign ratings. We report in Figure 5 GIRFs for Moody's over the 1998-2016 period using the first difference transformation; these are broadly in line with our main results reported earlier on. However, minor differences can be observed. For instance, a comparison of Figure 5 with Figure 1 shows that the impact of sovereign rating shocks on NPLs based on the logistic transformation against the linear transformation is statistically most long-lived (10 years for the former as opposed to 9 years for the latter case) and the impact of sovereign rating shocks on investments based 
on the linear transformation against the logistic transformation is statistically most longlived ( 9 years for the former as opposed to 7 years for the latter case).

\subsubsection{Alternative measures of uncertainty and banking risk}

Rather than using stock price volatility in our PVAR model, we have tried the economic policy uncertainty. ${ }^{21}$ Economic Policy Uncertainty is an index constructed based on newspaper articles regarding policy uncertainty from leading newspapers. It counts the number of newspaper articles containing the terms uncertain or uncertainty, economic or economy, and one or more policy-relevant terms.

Our GIRFs (see Figure 6) throughout the entire sample period for Moody's based on the first difference transformation are broadly in line with our main results reported earlier on. Notice, however (by comparing Figure 6 with Figure 1), that the impact of economic policy uncertainty on sovereign ratings is less long-lived than the impact of stock price volatility on sovereign ratings (i.e 5 years and 7 years).

As a further robustness check, rather than capturing banking risk considerations by NPLs, we have constructed for each country a 'banking risk' factor measure using principal component analysis (PCA). PCA is pooling information from a 4-variable dataset, namely NPLs, bank credit to bank deposits, bank capital to risk weighted assets and bank Z-score which contribute $22.42 \%, 26.11 \%, 23.99 \%$ and $27.48 \%$ to the 'banking risk' factor, respectively, while the 'banking risk' factor contributes $53.67 \%$ to the total variation of the 4-variable dataset (these are average numbers across countries). ${ }^{22}$ The bank capital to risk weighted assets is a measure of bank solvency and resiliency which shows the extent to which banks are able to 'weather the storm' of unexpected losses. The bank credit to bank deposits is a measure of liquidity (see e.g. the discussion in Klomp and de Haan, 2012). The bank Z-score captures the (inverse of the) probability of default of a country's banking system, calculated as a weighted average of the Z-scores of a country's

${ }^{21}$ For more information see Baker et al. (2016) and http://www.policyuncertainty.com/index.html. Because of data unavailability, a country specific index is only employed for 22 countries. For European countries without a country specific index, the aggregate European index is employed. In the case of nonEuropean countries without a country specific index, the Global policy uncertainty index is employed.

22 To ensure that an increase in the 'banking risk' factor indicates additional risk across countries, we have applied (at the country level) PCA to NPLs, bank credit to bank deposits, the inverse of bank capital to risk weighted assets and the inverse of bank Z-score. 
individual banks where a bank-specific Z-score compares a bank's buffers (capitalization and returns) with the volatility of those returns. From Figure 7, there is a statistically insignificant impact of shocks to the 'banking risk' factor on sovereign ratings and vice versa. Overall, these results suggest that NPLs dominate a pooling-based information from measures of banking risk in driving credit rating decisions. ${ }^{23}$

\subsubsection{Other robustness tests}

We have also explored the impact of regulatory quality; this pools information from a number of variables such as investment and financial freedom, business regulatory environment, competition policy, tax inconsistency, financial institution's transparency, public sector openness to foreign bidders and easiness to start new business. ${ }^{24}$ To keep the dimensionality of the PVAR manageable, and noting that regulatory quality is a policy variable (more likely to affect than be affected by other economic or financial variables), we let it enter as an exogenous one. Doing so made no qualitative difference to the results reported earlier one. ${ }^{25}$

\section{Conclusions}

This paper examines the joint behavior of sovereign ratings and its macroeconomic/financial drivers within a multivariate Panel Vector AutoRegressive framework. Using a panel of 72 countries over the 1998-2016 period, a number of findings stand out. First, our model finds an important role for NPLs in affecting sovereign rating assessment over and above the effects of uncertainty, GDP growth, government debt-to-GDP ratio, investment-to-GDP ratio and the fiscal balance-to-GDP ratio. At the same time, sovereign rating decisions themselves affect NPLs. Intuitively, sovereign rating downgrades trigger bank rating downgrades which in turn lead to a reduction in lending supply and, at the same time, increase the burden of re-financing existing loans,

\footnotetext{
${ }^{23}$ An alternative to PCA would involve running a country-specific dynamic factor model which relies, for instance, on the 4-variable dataset mentioned above to derive a latent banking risk factor. The countryspecific time series information set is too short to pursue this option.

${ }^{24}$ For more details see http://info.worldbank.org/governance/wgi/pdf/rq.pdf.

25 Jeanneret (2018) finds that government effectiveness as a measure of the ability of governments to collect and use fiscal revenues effectively leads to a reduction of sovereign credit spreads.
} 
therefore, triggering a rise in NPLs. Second, uncertainty shocks trigger sovereign rating downgrades following the financial turmoil and the subsequent Eurozone crisis.

By flagging the importance of rising NPLs as a vital banking risk factor, our model provides additional insight towards understanding how CRAs make their sovereign rating assessments. Both rising NPLs and increased uncertainty trigger sovereign rating downgrades that 'hit' investments and economic growth. With this in mind, it is in the interest of policymakers to be tackling uncertainty and NPLs especially since rising NPLs have been found themselves to undermine future economic growth (Balgova et al., 2016). This could be achieved by improving, for instance, governance indicators; indeed, Balgova et al. (2018) note that improved governance (as a measure of the quality of institutions) helps reduce NPLs and strengthen economic growth.

The focus of this paper has been on sovereign ratings. Credit Default Swaps provide a market-based measure of sovereign risk which is available at a higher frequency. Whether this links in the same manner as sovereign ratings to the lower frequency information set of fundamentals employed in our paper is an interesting avenue of future research that could be addressed through e.g. mixed data sampling (MIDAS) models. ${ }^{26}$ Future research could also focus on the potential role of state-owned versus private banks. For instance, Gonzalez-Garcia and Grigoli (2013) find that a larger presence of state-owned banks in the banking system is associated with more credit to the public sector, larger fiscal deficits, higher public debt ratios, and higher NPLs because these tend to be more sensitive to political interests if governance in these banks is weak. In addition, state-owned banks appear to have a higher fraction of NPLs loans than privately-owned banks and tend to display a higher likelihood of default (see the discussion in Cull et al., 2017 and references therein). These findings open up the possibility of exploring the interconnections among debt, NPLs and ultimately credit rating decisions in a panel VAR model which controls for governance indicators and a distinction between state-owned and private banks. We intend to return to these issues in future research.

\footnotetext{
${ }^{26}$ Berndt et al. (2018) show that CDS in the US corporate sector comove with macroeconomic indicators (namely the 5-year Treasury rate and the University of Michigan consumer sentiment index).
} 


\section{References}

Acharya, V., Drechsler, I. and Schnabl, P. (2014). A pyrrhic victory? Bank bailouts and sovereign credit risk. Journal of Finance, 69(6), 2689-2739.

Adelino, M. and Ferreira, M.A. (2016). Bank ratings and lending supply: Evidence from sovereign downgrades. Review of Financial Studies, 29(7), 1709-1746.

Afonso, A., Gomes, P. and Rother, P. (2011). Short and long-run determinants of sovereign debt credit ratings. International Journal of Finance and Economics, 16, 1-15.

Altavilla, C., Pagano, M. and Simonelli, S. (2017). Bank Exposures and Sovereign Stress Transmission. Review of Finance, 21, 2103-2139.

Andrews, D. and Lu, B. (2001). Consistent model and moment selection procedures for GMM estimation with application to dynamic panel data models. Journal of Econometrics, $101,123-164$.

Arellano, M. and Bover, O. (1995). Another look at the instrumental variable estimation of error-components model. Journal of Econometrics, 68(1), 29-51.

Baghai, R.P., Servaes, H., and Tamayo, A. (2014). Have rating agencies become more conservative? Implications for capital structure and debt pricing. Journal of Finance, 69, 1961-2005.

Balgova, M., Plekhanov, A. and Skrzypinska, A. (2018). Reducing non-performing loans: Stylized facts and economic impact. Paper presented at the 2018 Annual Meeting of the American Economic Association (held in Philadelphia, PA on January 5-7, 2018). Available at:

https://www.aeaweb.org/conference/2018/preliminary/3224?q=eNqrVipOLS70zM8 LqSxIVbKqhnGVrJQMlWp1lBKLi OTgRwlHaWS1KIcXAgrJbESKpSZmwphlWWmloO0Fx UUXDAFTA1AegsS00Gyxkq1XDBupR4W

Balgova, M., Nies, M. and Plekhanov, A. (2016). The economic impact of reducing nonperforming loans. European Bank for Reconstruction and Development (EBRD) Working Paper No. 193. Available at:

http://npl.vienna-initiative.com/wp-content/uploads/sites/2/2017/02/EBRD-TheEconomic-Impact-of-Reducing-NPLs-WP 193.pdf 
Baker, S.R., Bloom, N. and Davis, S.J. (2016). Measuring economic policy uncertainty. Quarterly Journal of Economics, 131, 1593-1636.

Berndt, A., Douglas, R., Duffie, D. and Ferguson, M. (2018). Corporate Credit Risk Premia. Review of Finance, 22, 419-454.

Binder, M., Hsiao, C. and Pesaran, M.H. (2005). Estimation and inference in short panel vector autoregressions with unit roots and cointegration. Econometric Theory, 21(4), 795-837.

Boumparis, P., Milas, C. and Panagiotidis, T. (2017). Economic policy uncertainty and sovereign credit rating decisions: Panel quantile evidence for the Eurozone. Journal of International Money and Finance, 79, 39-71.

Brůha, J. and Kočenda, E. (2018). Financial stability in Europe: Banking and sovereign risk. Journal of Financial Stability, 36, 305-321.

Chen, S.S., Chen, H.Y., Chang, C.C. and Yang, S.L. (2013). How do sovereign credit rating changes affect private investment? Journal of Banking and Finance, 37(12), 4820-4833.

Chen, S.S., Chen, H.Y., Chang, C.C. and Yang, S.L. (2016). The relation between sovereign credit rating revisions and economic growth. Journal of Banking and Finance, 64, 90-100. Cull, R., Martinez Peria, M.S. and Verrier, J. (2017). Bank Ownership: Trends and Implications. International Monetary Fund Working Paper No. 17/60.

De Moor, L., Luitel, P., Sercu, P., and Vanpée, R. (2018). Subjectivity in sovereign credit ratings. Journal of Banking and Finance, 88, 366-392.

Dimitrakopoulos, S. and Kolossiatis, M. (2016). State dependence and stickiness of sovereign credit ratings: evidence from a panel of countries. Journal of Applied Econometrics, 31, 1065-1082.

Drago, D. and Gallo, R. (2017a). The impact of sovereign rating changes on European syndicated loan spreads: the role of the rating-based regulation. Journal of International Money and Finance, 73, Part A, 213-231.

Drago, D. and Gallo, R. (2017b). The impact of sovereign rating changes on the activity of European banks. Journal of Banking and Finance, 85, 99-112. 
Drobetz, W., El Ghoul, S., Guedhami, O. and Janzen, M. (2018). Policy uncertainty, investment, and the cost of capital. Journal of Financial Stability, 39, 28-45.

Duygun, M., Ozturk, H. and Shaban, M. (2016). The role of sovereign credit ratings in fiscal discipline. Emerging Markets Review, 27, 197-216.

European Securities and Markets Authority (2016). ESMA's supervision of credit rating agencies, trade repositories and monitoring of third country central counterparties. 2016 Annual Report and 2017 Work Programme. Available at:

https://www.esma.europa.eu/sites/default/files/library/supervision annual report 2

\section{6 and work program 2017 0.pdf}

Gennaioli, N., Martin, A. and Rossi, S. (2014). Sovereign Default, Domestic Banks, and Financial Institutions. Journal of Finance, 69, 819-866.

Gilchrist, S., Sim, J., and Zakrajšek, E. (2014). Uncertainty, Financial Frictions, and Irreversible Investment. National Bureau of Economic Research Working Paper No. 20038.

Gonzalez-Garcia, J. and Grigoli, F. (2013). State-Owned Banks and Fiscal Discipline. International Monetary Fund Working Paper No. 13/206.

Holden, S., Natvik, G.J. and Vigier, A. (2018). Credit Rating and Debt Crises. International Economic Review, 59, 973-987.

Jeanneret, A. (2015). The Dynamics of Sovereign Credit Risk. Journal of Financial and Quantitative Analysis, 50, 963-985.

Jeanneret, A. (2018). Sovereign Credit Risk under Good/Bad Governance. Journal of Banking and Finance, 93, 230-246.

Kapetanios, G. (2008). A bootstrap procedure for panel data sets with many crosssectional units. Econometrics Journal, 11(2), 377-395.

Klomp, J. and de Haan, J. (2012). Banking risk and regulation: Does one size fit all? Journal of Banking and Finance, 36, 3197-3212.

Lugo, S., Croce, A. and Faff, R. (2015). Herding Behavior and Rating Convergence among Credit Rating Agencies: Evidence from the Subprime Crisis. Review of Finance, 19, 17031731. 
Mäkinen, T., Sarno, L. and Zinna, G. (2018). Risky Bank Guarantees. Available at: https://papers.ssrn.com/sol3/papers.cfm?abstract id=2925823

Obstfeld, M. (2018). The Current Economic Sweet Spot Is Not the "New Normal". International Monetary Fund blog, January 22, 2018. Available at:

https://blogs.imf.org/2018/01/22/the-current-economic-sweet-spot-is-not-the-newnormal/

Pástor, L. and Veronesi, P. (2013). Political Uncertainty and Risk Premia. Journal of Financial Economics, 110, 520-545.

Pesaran, H.H. and Shin, Y. (1998). Generalized impulse response analysis in linear multivariate models. Economics Letters, 58, 17-29.

Reusens, P. and Croux, C. (2017). Sovereign credit rating determinants: a comparison before and after the European debt crisis. Journal of Banking and Finance, 77, 108-121. S\&P’s Global Ratings (2017). Sovereign Rating Methodology. December 18, 2017. Available at:

https://www.spratings.com/documents/20184/4432051/Sovereign+Rating+Method ology/5f8c852c-108d-46d2-add1-4c20c3304725

Sigmund, M., \& Ferstl, R. (2019). Panel Vector Autoregression in R with the Package panelvar. The Quarterly Review of Economics and Finance. 
Table 1: Linear transformation of sovereign ratings

\begin{tabular}{|c|c|c|c|c|c|c|c|c|}
\hline & \multicolumn{3}{|c|}{ Rating Agency } & \multirow[b]{2}{*}{ Outlook } & \multicolumn{3}{|c|}{ Frequency } & \multirow{2}{*}{$\begin{array}{c}\text { Rating Scale } \\
(1-21)\end{array}$} \\
\hline & Fitch & S\&P's & Moody's & & Fitch & S\&P's & Moody's & \\
\hline \multirow[t]{2}{*}{ Highest quality } & \multirow[t]{2}{*}{ AAA } & \multirow[t]{2}{*}{ AAA } & \multirow[t]{2}{*}{ Aaa } & Stable & 249 & 249 & 291 & 21 \\
\hline & & & & Negative & 8 & 15 & 12 & 20.67 \\
\hline \multirow{9}{*}{ High quality } & \multirow{3}{*}{$\mathrm{AA}+$} & \multirow{3}{*}{$\mathrm{AA}+$} & \multirow{3}{*}{ Aa1 } & Positive & - & 11 & 3 & 20.33 \\
\hline & & & & Stable & 56 & 52 & 35 & 20 \\
\hline & & & & Negative & 3 & 11 & 9 & 19.67 \\
\hline & \multirow{3}{*}{ AA } & & & Positive & 3 & 4 & 7 & 19.33 \\
\hline & & AA & $\mathrm{Aa} 2$ & Stable & 61 & 40 & 50 & 19 \\
\hline & & & & Negative & 15 & 14 & 2 & 18.67 \\
\hline & & & & Positive & 4 & 2 & 10 & 18.33 \\
\hline & AA- & AA- & $\mathrm{Aa} 3$ & Stable & 34 & 41 & 35 & 18 \\
\hline & & & & Negative & 10 & 9 & 4 & 17.67 \\
\hline & & & & Positive & 8 & 9 & 12 & 17.33 \\
\hline & $A+$ & $\mathrm{A}+$ & $\mathrm{A} 1$ & Stable & 57 & 38 & 65 & 17 \\
\hline & & & & Negative & 8 & 7 & 4 & 16.67 \\
\hline & & & & Positive & 13 & 11 & 9 & 16.33 \\
\hline Strong payment & A & $\mathrm{A}$ & A2 & Stable & 45 & 66 & 54 & 16 \\
\hline capacity & & & & Negative & 2 & 10 & 7 & 15.67 \\
\hline & & & & Positive & 10 & 11 & 14 & 15.33 \\
\hline & $A-$ & $A-$ & A3 & Stable & 58 & 64 & 45 & 15 \\
\hline & & & & Negative & 9 & 6 & 10 & 14.67 \\
\hline & & & & Positive & 6 & 9 & 5 & 14.33 \\
\hline & $\mathrm{BBB}+$ & $\mathrm{BBB}+$ & Baa1 & Stable & 49 & 42 & 57 & 14 \\
\hline & & & & Negative & 17 & 12 & 10 & 13.67 \\
\hline Adequate payment & & & & Positive & 10 & 15 & 11 & 13.33 \\
\hline capacity & BBB & BBB & Baa2 & Stable & 58 & 57 & 43 & 13 \\
\hline & & & & Negative & 7 & 15 & 10 & 12.67 \\
\hline & & & & Positive & 10 & 7 & 28 & 12.33 \\
\hline & BBB- & BBB- & Baa3 & Stable & 83 & 59 & 64 & 12 \\
\hline & & & & Negative & 18 & 23 & 21 & 11.67 \\
\hline & & & & Positive & 12 & 14 & 15 & 11.33 \\
\hline & $\mathrm{BB}+$ & $\mathrm{BB}+$ & $\mathrm{Ba} 1$ & Stable & 46 & 35 & 52 & 11 \\
\hline & & & & Negative & 16 & 16 & 20 & 10.67 \\
\hline Likely to fulfil & & & & Positive & 4 & 19 & 7 & 10.33 \\
\hline obligations, ongoing & BB & BB & $\mathrm{Ba} 2$ & Stable & 37 & 52 & 23 & 10 \\
\hline uncertainty & & & & Negative & 12 & 23 & 8 & 9.67 \\
\hline & & & & Positive & 16 & 3 & 3 & 9.33 \\
\hline & BB- & BB- & $\mathrm{Ba} 3$ & Stable & 34 & 45 & 28 & 9 \\
\hline & & & & Negative & 6 & 9 & 6 & 8.67 \\
\hline & & & & Positive & 9 & 12 & 11 & 8.33 \\
\hline & $\mathrm{B}+$ & $\mathrm{B}+$ & B1 & Stable & 24 & 32 & 39 & 8 \\
\hline & & & & Negative & 4 & 5 & 7 & 7.67 \\
\hline & & & & Positive & 7 & 11 & 2 & 7.33 \\
\hline High credit risk & B & B & B2 & Stable & 27 & 26 & 24 & 7 \\
\hline & & & & Negative & 8 & 8 & 4 & 6.67 \\
\hline & & & & Positive & 3 & 3 & 6 & 6.33 \\
\hline & B- & B- & B3 & Stable & 24 & 42 & 36 & 6 \\
\hline & & & & Negative & 8 & 9 & 9 & 5.67 \\
\hline & & & & Positive & - & - & 4 & 5.33 \\
\hline & $\mathrm{CCC}+$ & $\mathrm{CCC}+$ & Caa1 & Stable & 2 & 18 & 13 & 5 \\
\hline & & & & Negative & 1 & 4 & 9 & 4.67 \\
\hline & & & & Positive & - & - & - & 4.33 \\
\hline Very high credit & $\mathrm{CCC}$ & CCC & Caa2 & Stable & 10 & - & 4 & 4 \\
\hline risk & & & & Negative & - & 2 & - & 3.67 \\
\hline & & & & Positive & - & - & - & 3.33 \\
\hline & CCC- & CCC- & Caa3 & Stable & - & - & 7 & 3 \\
\hline & & & & Negative & - & 3 & 2 & 2.66 \\
\hline Non default with & $\mathrm{CC}$ & CC & $\mathrm{Ca}$ & & - & - & - & 2.33 \\
\hline possibility of & & & & & & & & 2 \\
\hline recovery & $\mathrm{C}$ & & & & 3 & 3 & 4 & \\
\hline Default & DDD & SD & $\mathrm{C}$ & & & & & \\
\hline & DD & $\mathrm{D}$ & & & 8 & 10 & 1 & 1 \\
\hline & $\mathrm{D}$ & & & & & & & \\
\hline
\end{tabular}


Table 2: Data definitions and sources

\begin{tabular}{lll} 
Data Definitions & & \\
\hline Variable Name & Definition & Source \\
\hline Fitch rating & Sovereign rating attributed at 31st December of each year & Fitch \\
S\&P's rating & Sovereign rating attributed at 31st December of each year & S\&P's \\
Moody's rating & Sovereign rating attributed at 31st December of each year & Moody's \\
Uncertainty & Volatility of Stock Price Index & FRED \\
GDP growth rate & Gross domestic product, constant prices Percent change & IMF WEO April 2017 \\
Investments & Total investments as a percent of GDP & IMF WEO April 2017 \\
Government debt & General government gross debt as a percent of GDP & IMF WEO April 2017 \\
Fiscal Balance & General government net lending/borrowing as a percent of GDP & IMF WEO April 2017 \\
Non-performing loans & Non-performing loans as a percent of total gross loans & World Bank; FRED; IMF IFS \\
\hline
\end{tabular}

Table 3: Summary statistics of the data variables

\begin{tabular}{lccccccc} 
Variable & Min. & $\begin{array}{c}\text { 1st } \\
\text { Quartile }\end{array}$ & Median & Mean & $\begin{array}{c}\text { 3rd } \\
\text { Quartile }\end{array}$ & $\begin{array}{c}\text { Max. } \\
\text { Dev. }\end{array}$ \\
\hline $\begin{array}{l}\text { Moody's ratings } \\
\text { S\&P's }\end{array}$ & 1 & 11 & 15 & 14.84 & 20 & 21 & 5.10 \\
ratings & 1 & 10.33 & 15 & 14.46 & 19.67 & 21 & 5.12 \\
Fitch ratings & 1 & 11 & 15 & 14.87 & 20 & 21 & 4.90 \\
Uncertainty & 5.91 & 15.02 & 20.41 & 22.42 & 26.71 & 99.03 & 10.73 \\
GDP growth rate & -15.14 & 1.51 & 3.31 & 3.22 & 5.14 & 26.26 & 3.69 \\
Investments & 4.31 & 20.06 & 22.81 & 23.51 & 26.08 & 48.01 & 5.37 \\
Government debt & 0.06 & 29.48 & 44.13 & 51.48 & 66.89 & 242.11 & 33.51 \\
Fiscal Balance & -32.13 & -4.09 & -2.21 & -1.81 & 0.04 & 29.80 & 4.53 \\
Non-performing loans & 0.08 & 1.79 & 3.61 & 6.61 & 8.60 & 71.70 & 7.81 \\
\hline
\end{tabular}


Figure 1: Generalized impulse response functions for Moody's using first difference transformation
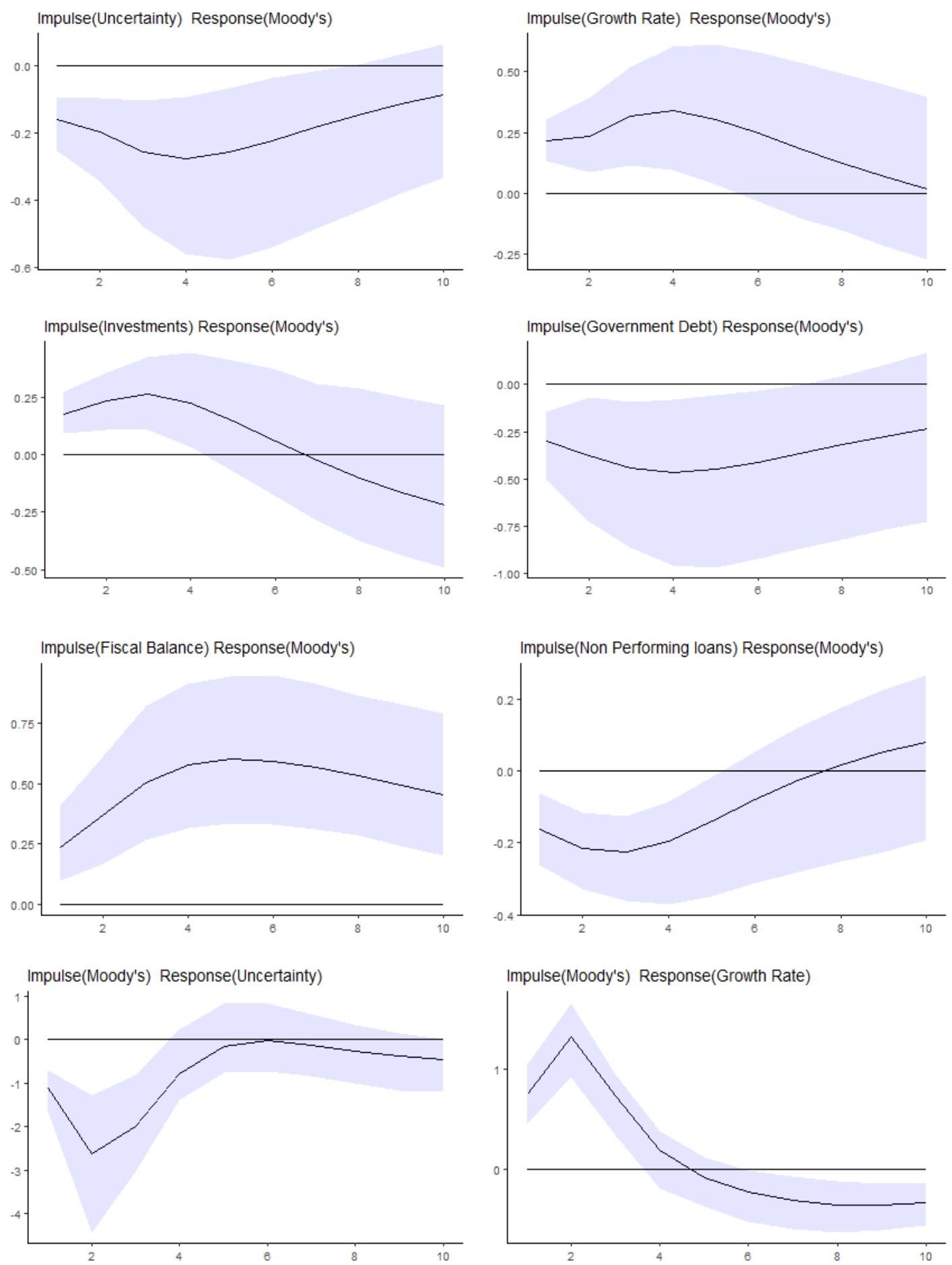
Figure 1 (continued): Generalized impulse response functions for Moody's using first difference transformation
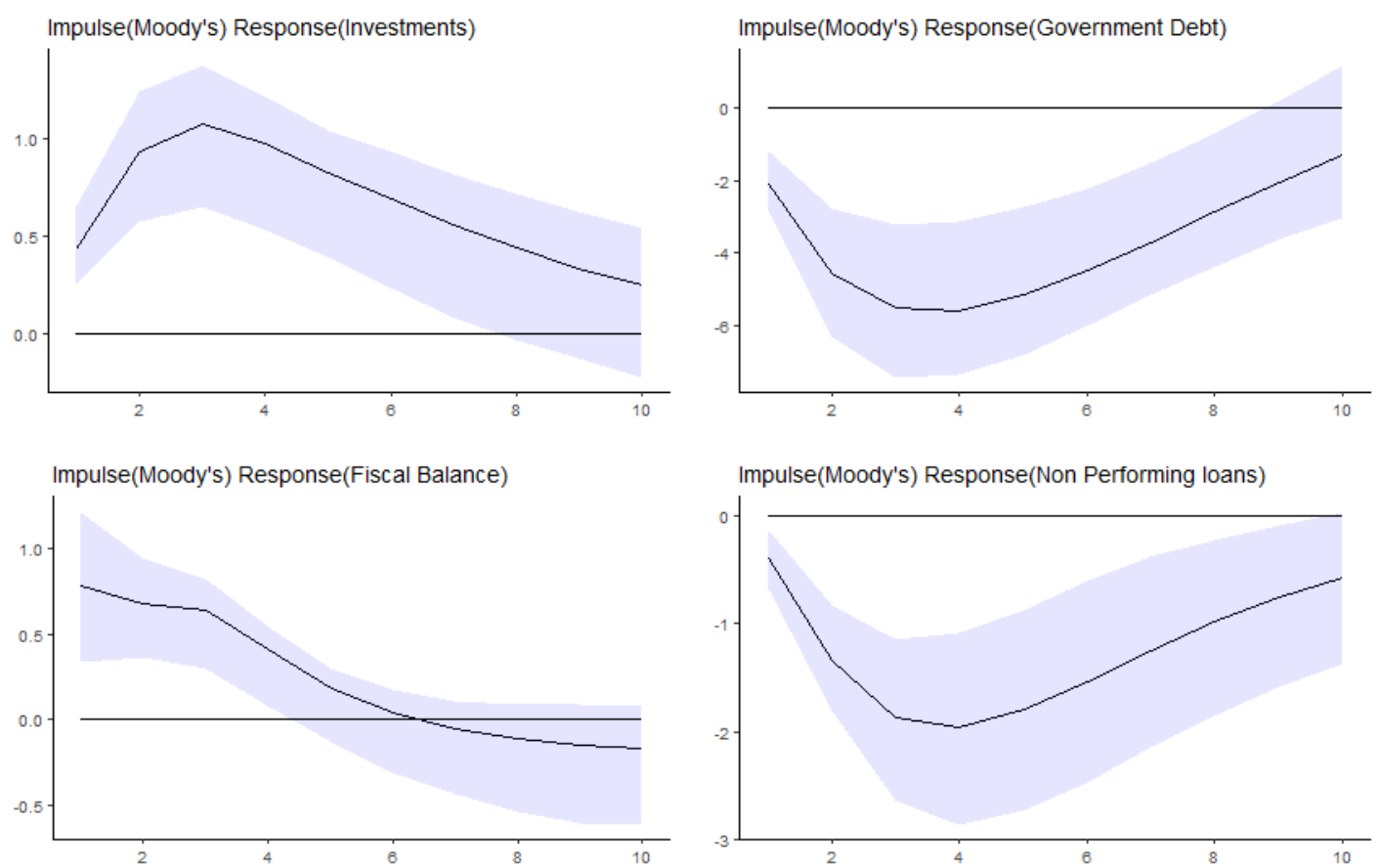

Notes: Shaded areas refer to the $95 \%$ confidence intervals based on 500 bootstrap replications. Generalized impulse response functions are based on estimates of the Panel Vector AutoRegressive (PVAR) model (2) in Section 3 of the paper where the endogenous variables in our PVAR model are

$\mathrm{y}_{i, t}=$ [Stock price volatility, GDP growth, Investments, Debt, Fiscal Balance, NPLs, rating] using the rating of Moody's and the first difference transformation. 
Figure 2: Generalized impulse response functions for S\&P's using first difference transformation
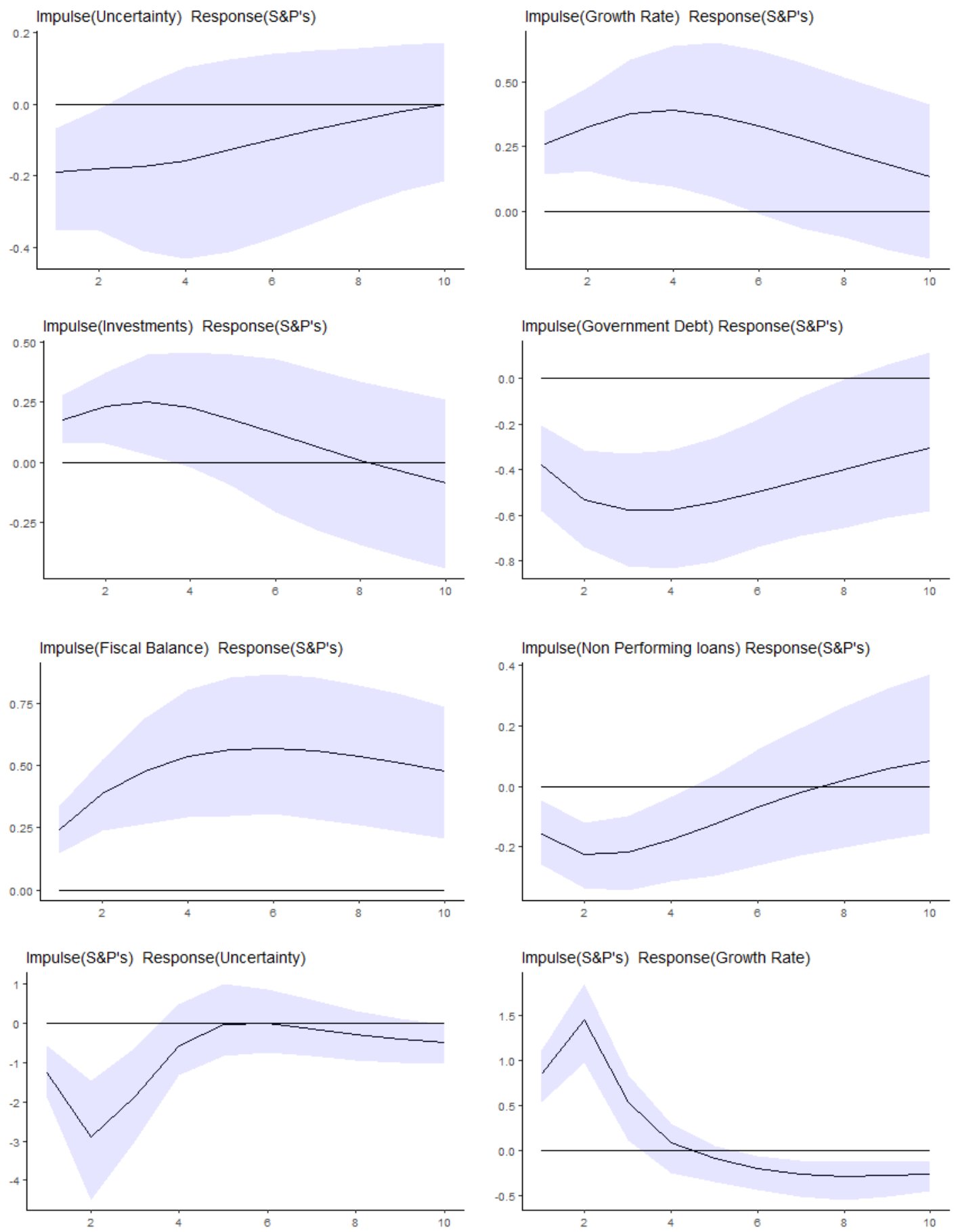
Figure 2 (continued): Generalized impulse response functions for S\&P’s using first difference transformation
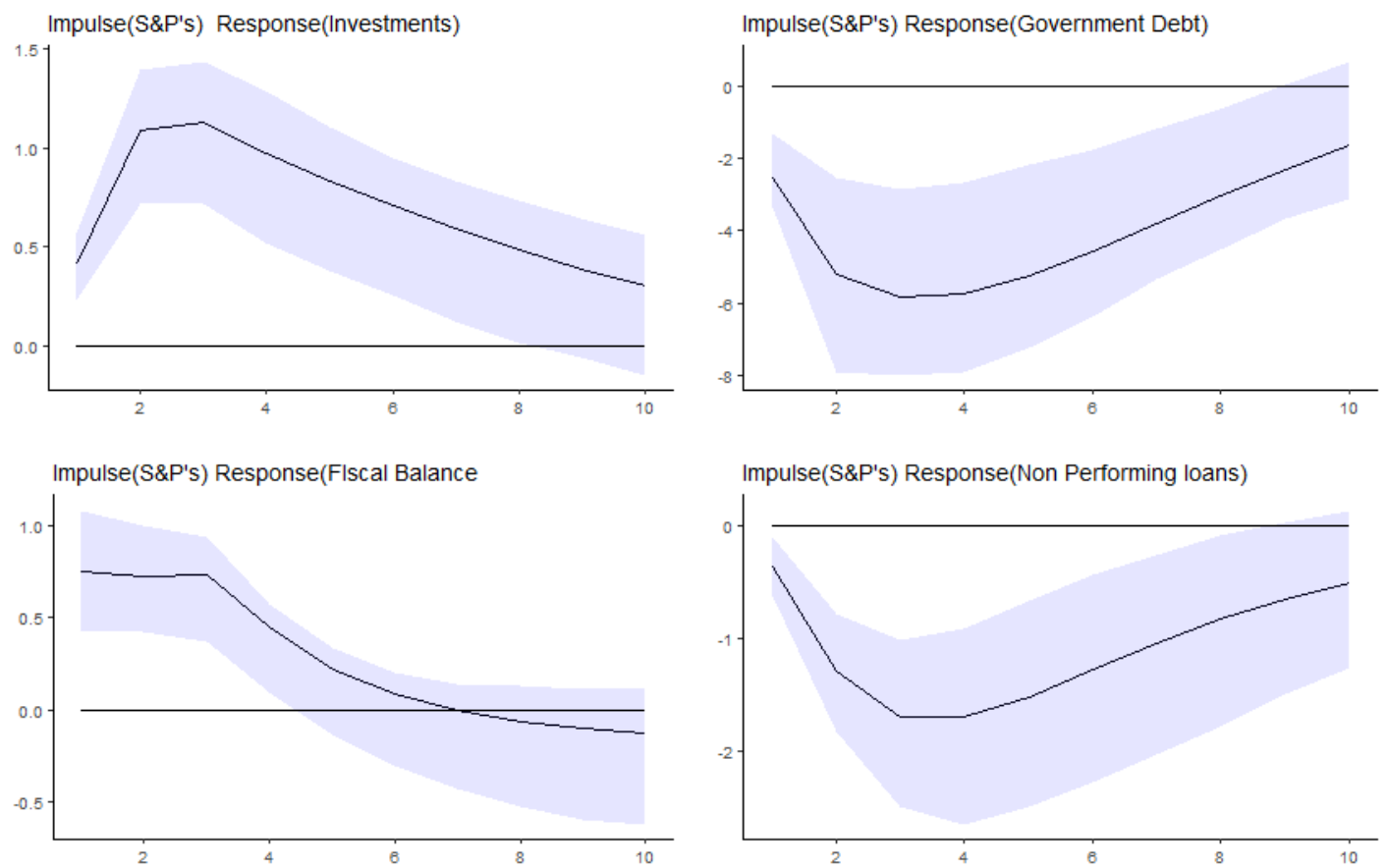

Notes: Shaded areas refer to the $95 \%$ confidence intervals based on 500 bootstrap replications. Generalized impulse response functions are based on estimates of the Panel Vector AutoRegressive (PVAR) model (2) in Section 3 of the paper where the endogenous variables in our PVAR model are

$\mathrm{y}_{i, t}=$ [Stock price volatility, GDP growth, Investments, Debt, Fiscal Balance, NPLs, rating] using the rating of S\&P's and the first difference transformation. 
Figure 3: Generalized impulse response functions for Fitch using first difference transformation
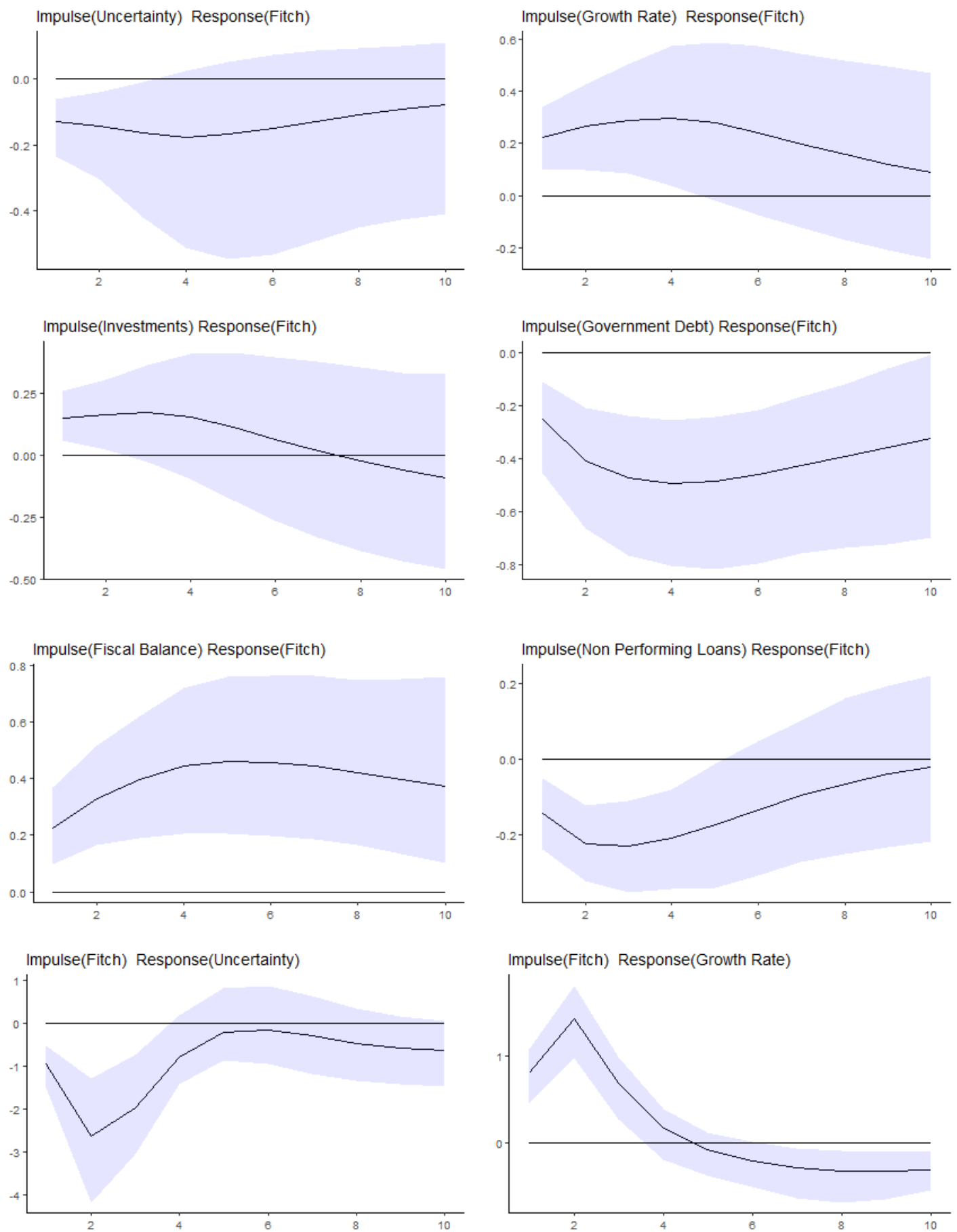
Figure 3 (continued): Generalized impulse response functions for Fitch using first difference transformation
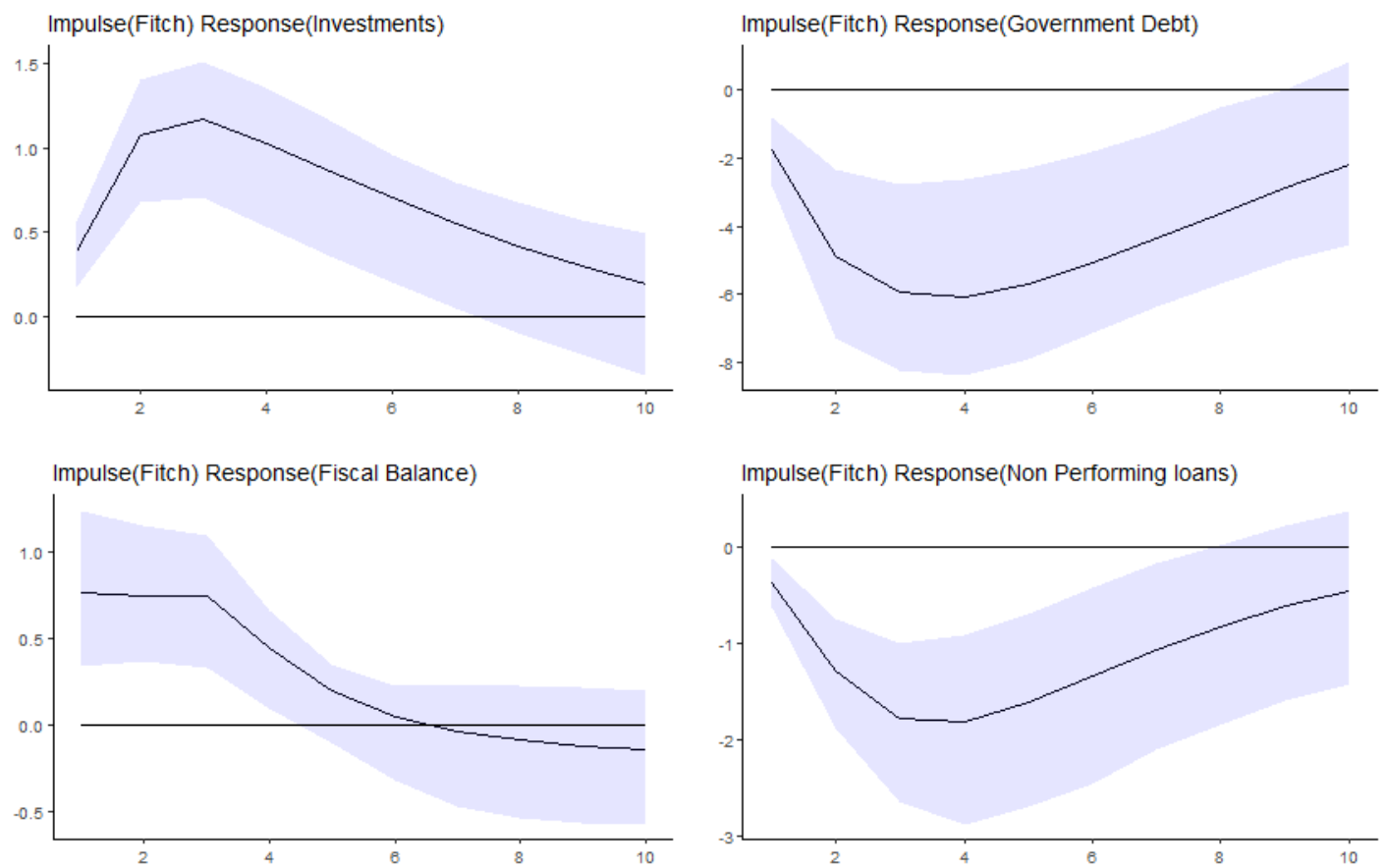

Notes: Shaded areas refer to the $95 \%$ confidence intervals based on 500 bootstrap replications. Generalized impulse response functions are based on estimates of the Panel Vector AutoRegressive (PVAR) model (2) in Section 3 of the paper where the endogenous variables in our PVAR model are

$\mathrm{y}_{i, t}=$ [Stock price volatility, GDP growth, Investments, Debt, Fiscal Balance, NPLs, rating] using the rating of Fitch and the first difference transformation. 
Figure 4: Linear and logistic transformation of sovereign credit ratings for Moody's

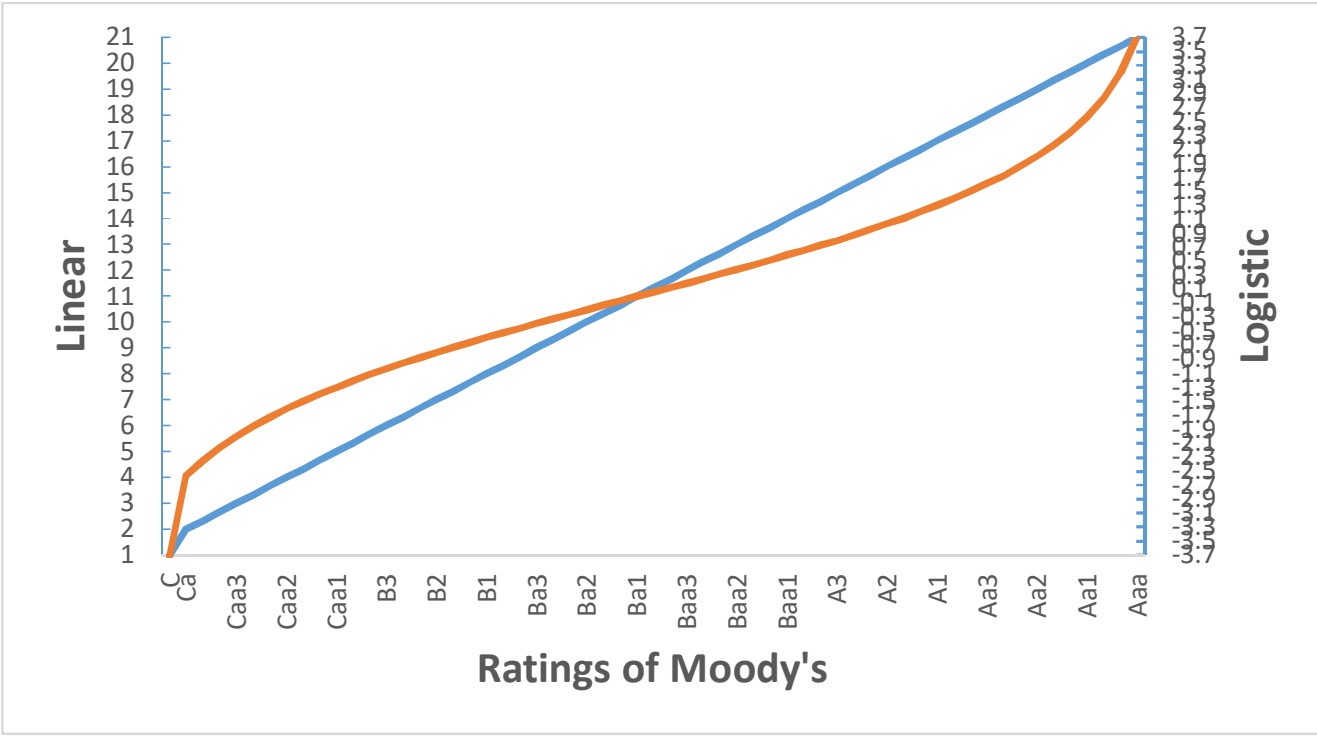


Figure 5: Generalized impulse response functions for Moody's using logistic transformation of sovereign ratings
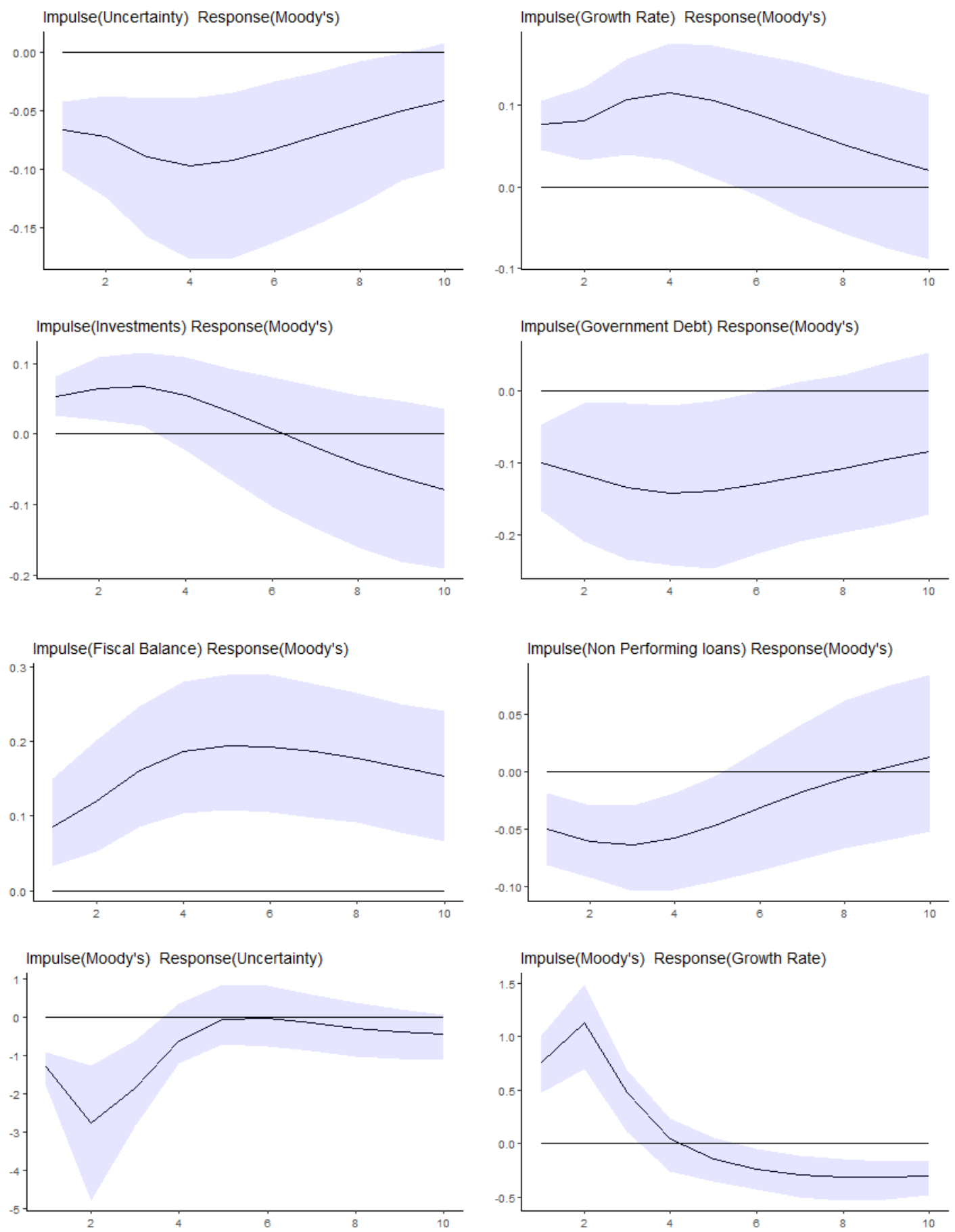
Figure 5 (continued): Generalized impulse response functions for Moody's using logistic transformation of sovereign ratings
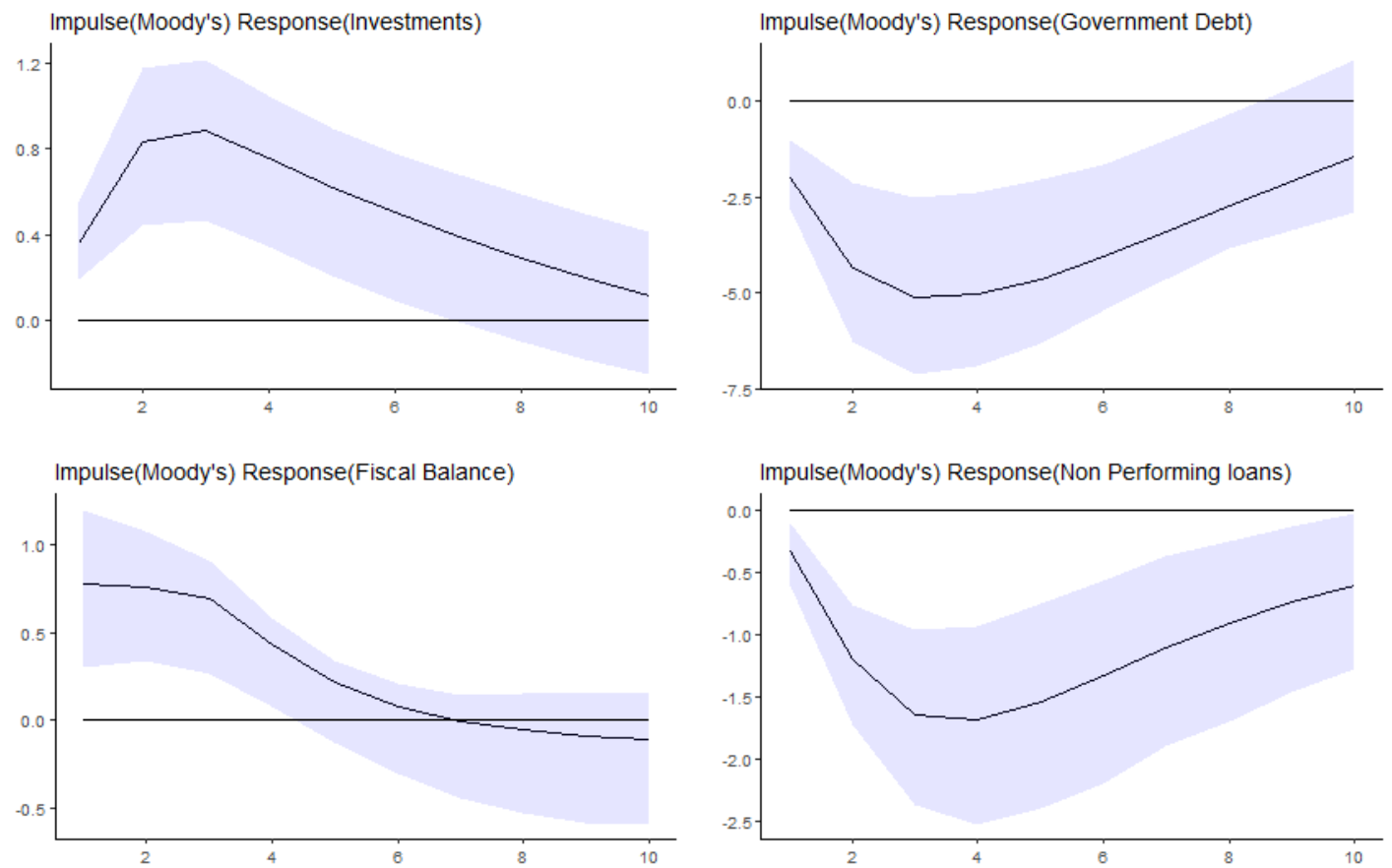

Notes: Shaded areas refer to the $95 \%$ confidence intervals based on 500 bootstrap replications. Generalized impulse response functions are based on estimates of the Panel Vector AutoRegressive (PVAR) model (2) in Section 3 of the paper (using the first difference transformation) where the endogenous variables in our PVAR model are

$\mathrm{y}_{i, t}=$ [Stock price volatility, GDP growth, Investments, Debt, Fiscal Balance, NPLs, rating $]$ using the logistic transformation of the rating of Moody's. 
Figure 6: Generalized impulse response functions for Moody's using Economic Policy Uncertainty
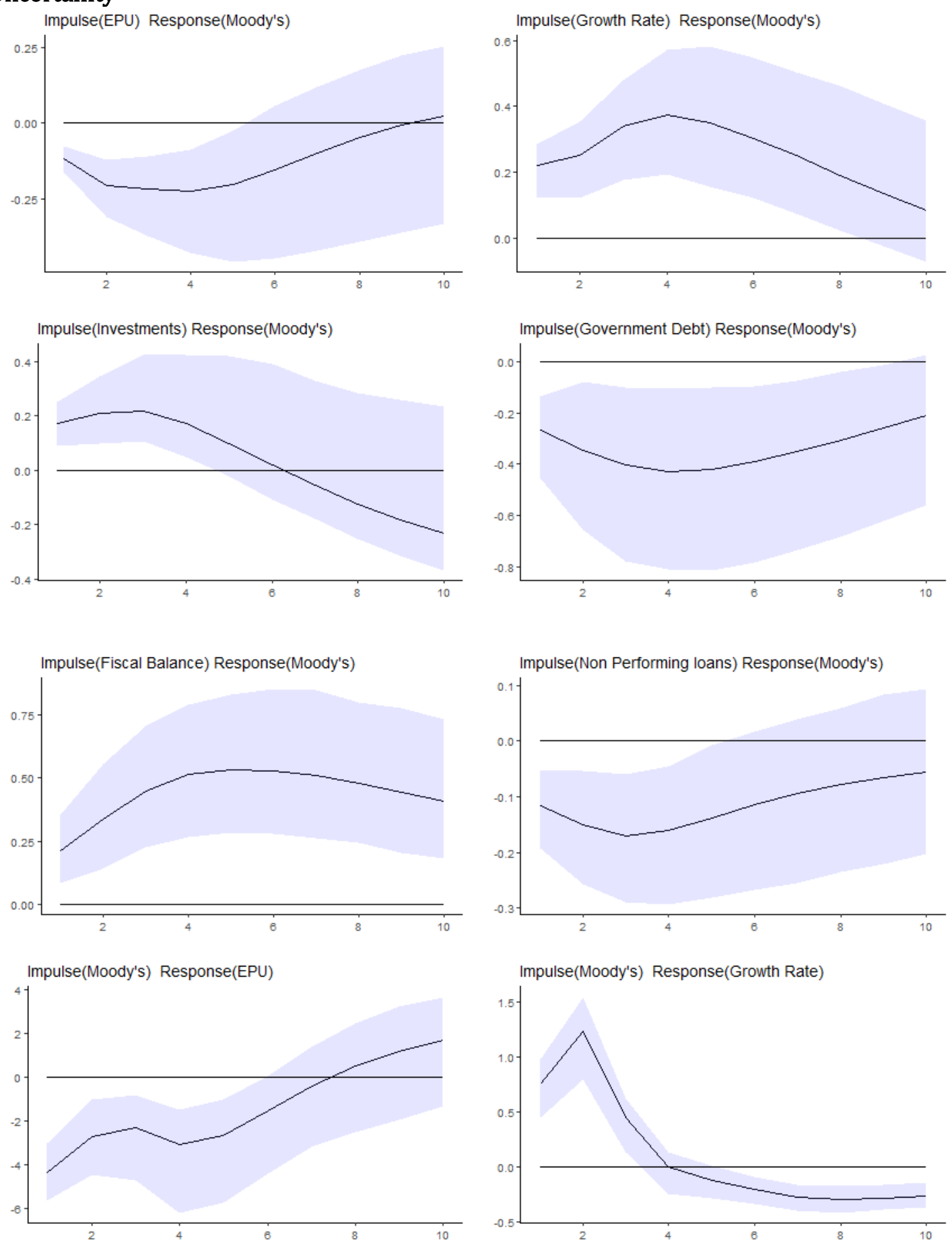
Figure 6 (continued): Generalized impulse response functions for Moody's using Economic Policy Uncertainty
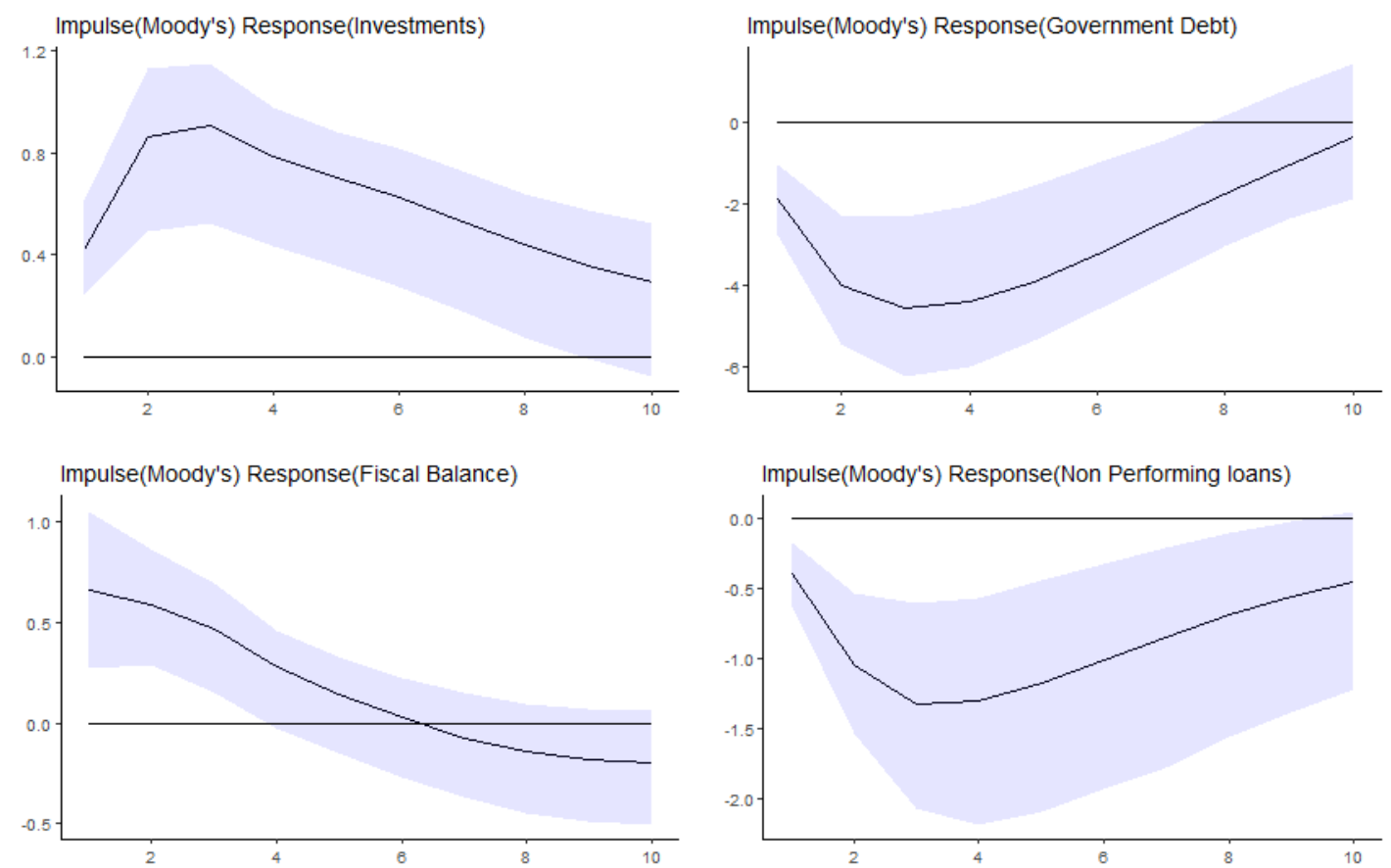

Notes: Shaded areas refer to the $95 \%$ confidence intervals based on 500 bootstrap replications. Generalized impulse response functions are based on estimates of the Panel Vector AutoRegressive (PVAR) model (2) in Section 3 of the paper where the endogenous variables in our PVAR model are

$\mathrm{y}_{i, t}=$ [Economic Policy Uncertainty, GDP growth, Investments, Debt, Fiscal Balance, NPLs, rating] using the rating of Moody's and the first difference transformation. 
Figure 7: Generalized impulse response functions for Moody's using the banking risk factor
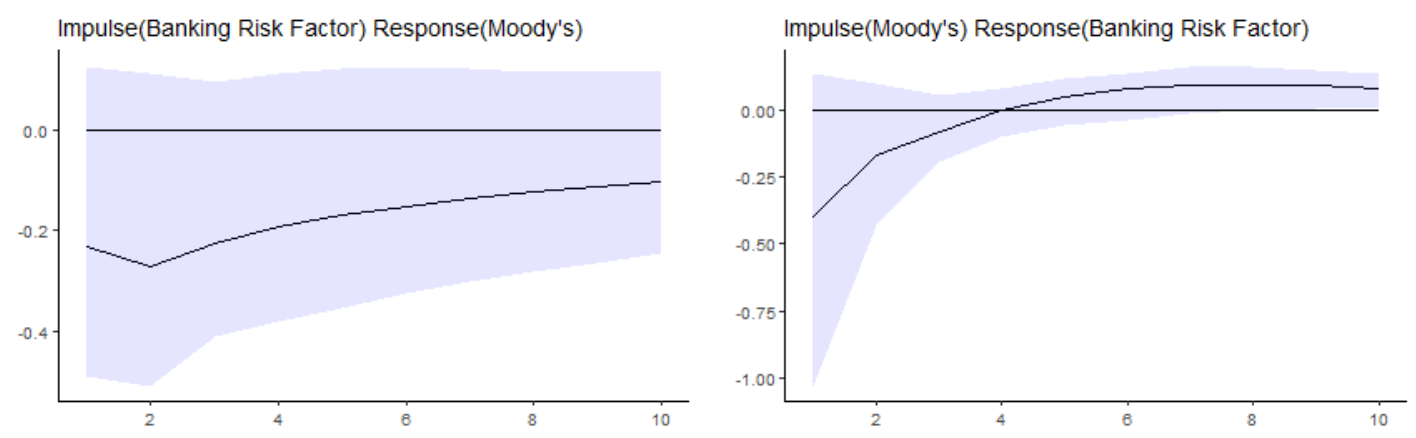

Notes: Shaded areas refer to the $95 \%$ confidence intervals based on 500 bootstrap replications. Generalized impulse response functions are based on estimates of the Panel Vector AutoRegressive (PVAR) model (2) in Section 3 of the paper where the endogenous variables in our PVAR model are

$\mathrm{y}_{i, t}=$ [Uncertainty, GDP growth, Investments, Debt, Fiscal Balance, banking risk factor, rating] using the rating of Moody's and the first difference transformation. 